\title{
Rainfall trends over 40 years in the Cobres River basin, Portugal: variability and impacts
}

\author{
RICHARDE MARQUES DA SILVA ${ }^{\mathbf{1}}$, CELSO A. G. SANTOS ${ }^{\mathbf{1}}$, \\ MADALENA MOREIRA ${ }^{2}$, JOÃO CORTE-REAL ${ }^{2} \&$ \\ ROBERTA DE CARVALHO BARBOSA ${ }^{1}$
}

1 Federal University of Paraiba, Department of Geosciences, 58051-900 João Pessoa, PB, Brazil richarde@geociencias.ufpb.br, celso@ct.ufpb.br

2 Institute of Mediterranean Agrarian and Environmental Sciences (ICAAM), Group Water, Soil and Climate, University of Evora, Núcleo da Mitra, 7002-774 Evora, Portugal

\section{INTRODUCTION}

Climate change has been the most important topic in climatic research of the last few decades around the world. Global warming and, therefore, changes in annual precipitation, have attracted the attention of the researchers in different regions of the world. One of the most significant consequences of the identified global warming would be an increase or decrease in the magnitude and frequency of annual precipitation generated (Santos and Morais 2013). Changes in annual precipitation have been identified in many studies conducted at local, regional or global scales (Silva et al. 2013). The main objective of this study is analysis of the trends in annual precipitation at a regional scale over 40 years (1960-2000) in the Cobres River basin, southern Portugal $\left(37^{\circ} 28^{\prime} \mathrm{N}-37^{\circ} 57^{\prime} \mathrm{N}, 8^{\circ} 10^{\prime} \mathrm{W}-7^{\circ} 51^{\prime} \mathrm{W}\right)$, using statistical tools. This region is a typical semi-arid basin, middle-sized with an area of $1194 \mathrm{~km}^{2}$, located in Alentejo province, an area suffering from desertification. It is a region of relatively low relief, with elevation varying from 103 to $308 \mathrm{~m}$ a.s.l. The climate in this region is characteristically Mediterranean and Continental, with moderate winters and hot and dry summers, a high daily temperature range, and a weak and irregular precipitation regime; mean annual precipitation of raingauge stations in the region varies between 400 and $900 \mathrm{~mm}$, with around 50 to 80 rainy days per year.

\section{MATERIAL AND METHODS}

Datasets of daily rainfall recorded at eight weather stations were analysed (Almodovar, Castro Verde, Salvada, Serpa, São Marcos da Atoboeira, Trindade, Aldeia dos Palheiros and Aljustrel). In this study, daily data from eight rainfall and three river flow stations for the period 1960-2000, obtained from the Sistema Nacional de Informação de Recursos Hídricos, available at http://www.snirh.pt, were used to study the seasonality and trends on an annual basis. The nonparametric Mann-Kendall and Sen's methods were used to determine whether there was a positive or negative trend in weather data with their statistical significance. A detailed statistical analysis applied to the rainfall time series of all gauges indicates that rainfall is highly temporally variable and there is a decrease in the annual rainfall amount for the period studied (1960-2000). However, there are no signs of any significant rainfall reduction in the basin, and in fact, some raingauges show a small rainfall increase during the recent decades. In this study, the trends of rainfall in the basin were analysed by the Mann-Kendall (Kendall 1975) and the Sen's slope (Sen 1968) tests. Their efficiency and power have already been demonstrated for similar applications.

\section{RESULTS AND DISCUSSION}

Figure 1 presents the rainfall anomaly and mean annual rainfall for Cobres River basin between 1960 and 2000. The space-time rainfall variability was relatively low (i.e. relative standard deviations were typically $<33 \%$ ) with the exception of raingauges Serpa, São Marcos da Atoboeira, Trindade and Aljustrel. The average annual rainfall within the study area is $549 \mathrm{~mm}$, and the highest value was $900 \mathrm{~mm}$ in 1989, and the lowest was $338 \mathrm{~mm}$ in 1998 . Observing the decades separately, it appears that the smallest average rainfall depths occurred during 1960, 1963, 


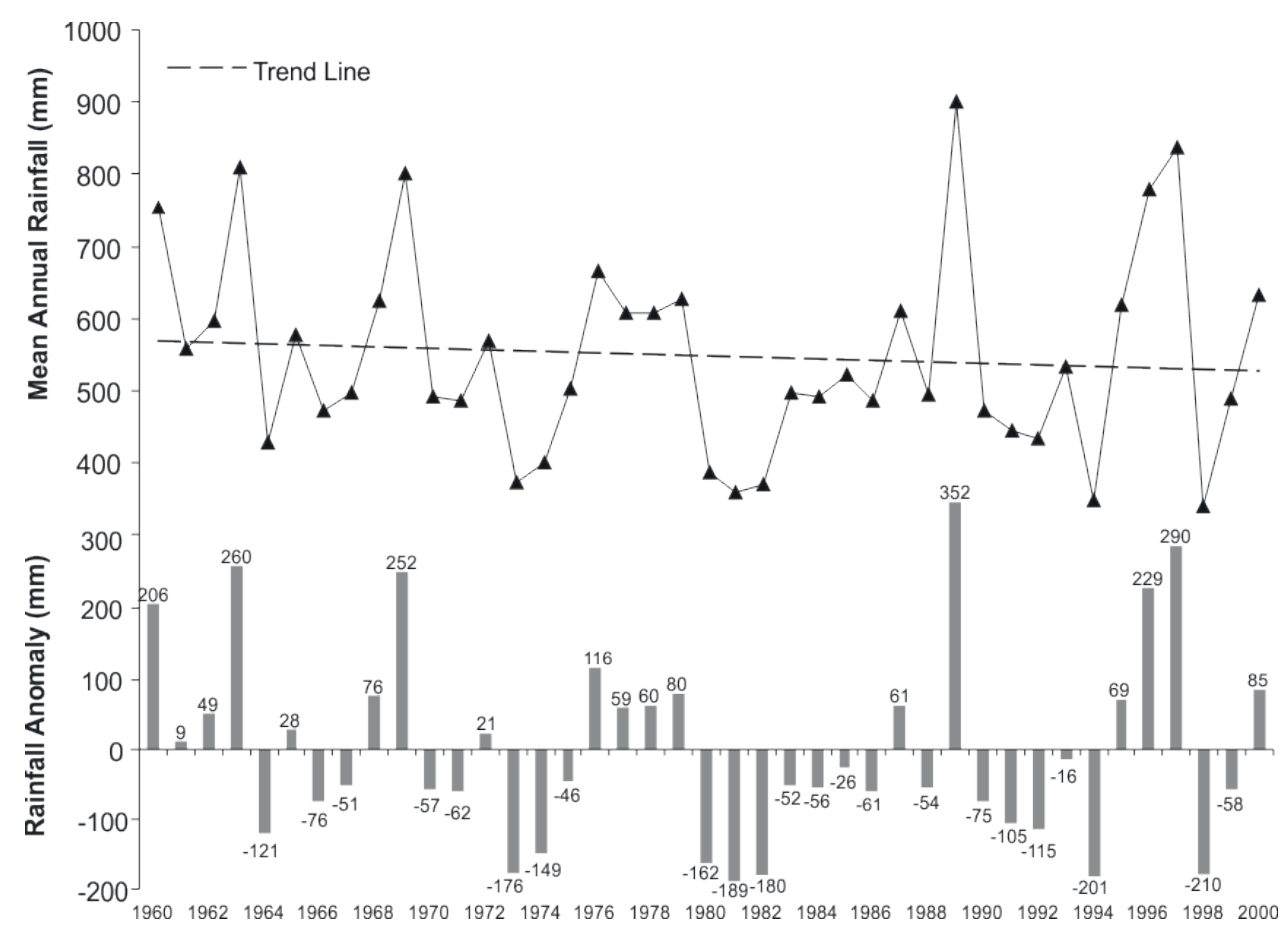

Fig. 1 Rainfall anomaly and mean annual rainfall for Cobres River basin between 1960 and 2000.

1989, 1996 and 1997, i.e. 750 to $900 \mathrm{~mm}$. The large annual variability of precipitation observed in this study has been shown to be affected by a few large-scale patterns of atmospheric circulation variability, particularly between 1960 and 2000 (Espírito Santo et al. 2013). Among these patterns the most relevant corresponds to the North Atlantic Oscillation that controls to a large extent the surface climate of Europe in general, and dominates the precipitation regime of Portugal in particular.

The tests of Sen and Mann-Kendall were also applied to the data series of annual rainfalls of the eight selected stations and detected a significant decreasing trend in all raingauges, at a significance level of 5\% for one raingauge and seven were better than $10 \%$. Only the Aljustrel raingauge, in the northwest of the studied basin, presents a significant decreasing trend at $5 \%$ significance level. This station is kind of isolated in the region. Nevertheless, this result indicates a specific regional behaviour for that period. The test revealed that the other series present important positive or negative variations, indicating the alternating presence of very rainy and very dry periods. The intersection point between both curves (forward and backward) within the confidence interval indicates approximately the change point that corresponds to the break date.

The results seem integrated to the global and European continental scale findings: decreasing trends are dominant for almost all indices; most of the calculated slopes are statistically insignificant; the distribution of positive and negative slopes in the area is extremely irregular and the changes in the basin are more significant compared to other studies.

\section{REFERENCES}

Espírito Santo, F., et al. (2013) Seasonal changes in daily precipitation extremes in mainland Portugal from 1941 to 2007. Regional Environment Change.

Kendall, M.G. (1975) Rank Correlation Methods. Griffin, London, UK.

Santos, C.A.G. and Morais, B.S. (2013) Identification of precipitation zones within São Francisco River basin (Brazil) by global wavelet power spectra. Hydrological Science Journal 58(4), 789-796. doi:10.1080/02626667.2013.778412.

Sen, P.K. (1968) Estimates of the regression coefficient based on Kendall's tau. Journal of the American Statistical Association $63,1379-1389$.

Silva, R.M., et al. (2013) Space-time variability of rainfall and hydrological trends in the Alto São Francisco River basin. In: Climate and Land Surface Changes in Hydrology (ed. by E. Boegh et al.), IAHS Publ. 359, 48-54. 